\title{
Effect of sugarcane waste in the control of interrill erosion
}

\section{Efeito de resíduos vegetais de cana-de-açúcar no controle da erosão hídrica entressulcos}

\author{
Wander Cardoso Valim ${ }^{1}$; Elói Panachuki ${ }^{2 *}$; Dorly Scariot Pavei ${ }^{1}$; \\ Teodorico Alves Sobrinho ${ }^{3}$; Wilk Sampaio Almeida ${ }^{4}$
}

\begin{abstract}
The cultivation of sugarcane uses different cropping systems that result in varying quantities of crop waste, this may influence soil erosion. The objective of this study was to evaluate the loss of soil and water, the infiltration rate, and soil surface roughness in an area cultivated with sugarcane (Saccharum spp.). Six treatments with different levels of plant waste were evaluated: sugarcane without plant waste; sugarcane with $4.0 \mathrm{Mg} \mathrm{ha}^{-1}$ of waste; sugarcane with $8.0 \mathrm{Mg} \mathrm{ha}^{-1}$ of waste; sugarcane with $12.0 \mathrm{Mg} \mathrm{ha}^{-1}$ of waste; sugarcane with $16.0 \mathrm{Mg} \mathrm{ha}^{-1}$ of waste; and burned sugarcane. The treatments were arranged in a randomized block design with four replications, totalling 24 experimental plots. As soil depth increased, there is reduction in macroporosity, total soil porosity, organic carbon content, mean geometric diameter and weighted mean diameter of the soil aggregates, whereas the bulk density of the soil displays the opposite trend. The presence of sugarcane waste on the soil surface increases the time required for the initiation of surface runoff. Sugarcane waste does not alter soil surface roughness, and at the minimum amount of waste administered ( $\left.4 \mathrm{Mg} \mathrm{ha}^{-1}\right)$ reduces losses of soil and water and increases the infiltration rate. The lack of soil surface coverage after harvesting the sugarcane contributes to soil and water loss, and reduces the rate of stable infiltration of water into the soil.
\end{abstract}

Key words: Saccharum spp. Simulated rain. Soil and water loss.

\section{Resumo}

O cultivo da cana-de-açúcar utiliza diferentes sistemas de colheita, resultando em quantidades variadas de resíduos vegetais, que podem influenciar no processo erosivo. O objetivo foi avaliar as perdas de solo e de água, a taxa de infiltração e a rugosidade superficial do solo em área cultivada com cana-deaçúcar (Saccharum ssp.). Foram utilizados seis tratamentos com diferentes níveis de resíduos vegetais: cana crua sem resíduo vegetal; cana crua com 4,0 $\mathrm{Mg} \mathrm{ha}^{-1}$ de resíduo; cana crua com 8,0 $\mathrm{Mg} \mathrm{ha}^{-1}$ de resíduo; cana crua com 12,0 $\mathrm{Mg} \mathrm{ha}^{-1}$ de resíduo; cana crua com 16,0 $\mathrm{Mg} \mathrm{ha}^{-1}$ resíduo e cana queimada. Os tratamentos dispostos no esquema experimental de blocos casualizados, com quatro repetições, totalizaram 24 parcelas experimentais. Com o aumento da profundidade do solo verifica-se redução da macroporosidade, da porosidade total do solo, do teor de carbono orgânico, do diâmetro médio geométrico e do diâmetro médio ponderado dos agregados do solo enquanto os valores de densidade do solo apresentam comportamento inverso. A presença de resíduos vegetais de cana-de-açúcar sobre a superfície do solo aumenta o intervalo de tempo necessário para o início do escoamento superficial. A palhada de cana-de-açúcar não altera a rugosidade superficial do solo e a quantidade mínima avaliada,

\footnotetext{
1 Discentes de Mestrado do Programa de Pós Graduação em Agronomia, Universidade Estadual de Mato Grosso do Sul, UEMS, Aquidauana, MS, Brasil. E-mail: wander.cv@hotmail.com; dorlyscariotpavei@yahoo.com.br

2 Prof. Dr., Programa de Pós-Graduação em Agronomia, UEMS, Aquidauana, MS, Brasil. E-mail: eloip@uems.br

3 Prof. Dr., Universidade Federal de Mato Grosso do Sul, UFMS, Campo Grande, MS, Brasil. E-mail: teodorico.alves@ufms.br

4 Discente de Doutorado em Agronomia, Universidade Federal Rural do Rio de Janeiro, UFRRJ, Seropédica, RJ, Brasil. E-mail: rondoniaws@gmail.com

* Author for correspondence
} 
de $4 \mathrm{Mg} \mathrm{ha}^{-1}$ de resíduo, apresenta eficiência na redução das perdas de solo e de água e no aumento da taxa de infiltração. A ausência de cobertura do solo após a colheita da cana-de-açúcar, favorece a ocorrência das perdas de solo e de água e reduz a taxa de infiltração estável de água no solo.

Palavras-chave: Saccharum ssp. Chuva simulada. Perdas de solo e de água.

\section{Introduction}

The success of a particular agricultural activity depends, in part, on knowledge of the factors contributing to soil erosion, such as rain and soil attributes. These factors, in conjunction with anthropic actions, may accelerate or slow down the erosive process. Thus, inadequate management of soil in sugarcane cultivation, the world market production of which is led by Brazil, results in losses of soil, water, and nutrients, causing reductions in crop productivity.

A few methods have been developed in the cultivation of sugarcane, such as the burning of waste (i.e., tops and leaves), to better facilitate the collection, transportation, and processing of sugarcane stalks (GALDOS et al., 2009). However, sugarcane harvesting by pre-burning waste leads to environmental damage, and eliminates soil biomass, which provides coverage to the soil (SOUZA et al., 2005). In addition, soil remaining uncovered for relatively long periods accelerates the erosive process, culminating in the physical, chemical, and biological degradation of the soil by the actions of rain and runoff.

Consequently, for economic and environmental reasons, the harvesting of sugarcane without preburning plant waste on the soil is increasingly being adopted in the sugarcane-producing areas of Brazil (GALDOS et al., 2009) by the introduction of mechanical harvesting machines. By itself, vegetative cover is an intervening factor in the erosive process, influencing runoff and changing the rate of water infiltration into the soil. Its presence on the soil surface intercepts falling raindrops and dissipates their kinetic energy, which prevents soil breakdown and provides a form of surface sealing (PANACHUKI et al., 2006; CARVALHO et al., 2009). Thus, the maintenance of some sugarcane waste on the soil surface, and its decomposition over time, has physical effects on the soil, such as the maintenance of soil moisture (TOMINAGA et al., 2002), the facilitation of aggregate stability, increase in water infiltration into the soil (GRAHAM et al., 2002), and alterations to soil organic matter content in areas that do not employ pre-harvest burning (ROBERTSON, 2003).

In a study evaluating the effect of sugarcane harvest systems on physical properties of the soil, Ceddia et al. (1999) found a significant increase in total porosity and the rate of water infiltration into the soil surface layer, in a sugarcane cultivation area in which plant waste was maintained. By contrast, in a sugarcane harvest with a pre-harvest burn, there was a decrease in the mean weighted diameter of stable aggregates in water and an increase in the density of the soil. Similarly, Bezerra and Cantalice (2006) reported that sugarcane waste promotes the increased interception of rain and water infiltration into the soil, minimizing soil and water loss during the crop cycle.

Thus, the favorable effect of surface roughness on the increase in the rate of infiltration and the consequent reduction of runoff is widely used (BERTOL et al., 2007). In fact, surface roughness has a positive effect on soil and water conservation, but there is no clear trend regarding differences between the effects of different types of plant waste in an annual crop (AMARAL et al., 2013). Currently, the efficacy of sugarcane plant residues, in relation to the factors discussed above, has not been evaluted.

Although the positive effect of vegetative cover on physical, chemical, and biological soil processes is well known, few studies have quantified the optimal amount of sugarcane waste in the reduction of soil erosion. This is important, because plant 
waste produced by the cultivation of different crops can be used as fuel for energy production, as is the case for sugarcane. For different quantities of waste on the soil surface, it is possible to quantify the loss of soil and water and the infiltration of water into the soil, and assess its effect on erosion and runoff. Thus, one can then determine what minimum level of vegetative cover is necessary to successfully reduce water erosion to acceptable levels, in order to recommend how much waste can be removed for other uses in sugarcane production without impairing the conservation of soil and water. The use of portable rainfall simulators allows this question to be answered, and is easily repeatable and cost-effective.

In this study, we evaluated the effect of different quantities of sugarcane waste on the rate of interrill erosion, infiltration of water into the soil, and on soil surface roughness.

\section{Material and Methods}

The experiment was conducted in an area cultivated with sugarcane (Saccharum spp.) under a no-till system. The soil of the experimental area, which has a smoothly undulating topography and a mean slope of $0.03 \mathrm{~m} \mathrm{~m}^{-1}$, was classified by Schiavo et al. (2010), as typical Dystrophic Red Argisol with sandy loam texture. The physical attributes of the soil (soil bulk density, macroporosity, total porosity, mean geometric diameter and weighted mean diameter), organic carbon, loss of soil and water, and the infiltration of water under simulated rainfall were evaluated after the crop had been harvested. Initially, the physical attributes of the soil were characterized at depth ranges of $0.00-0.10,0.10$ 0.20 , and $0.20-0.40 \mathrm{~m}$.

We used six treatments to evaluate the effect of six levels of sugarcane waste on the loss of soil and water, and on the rate of water infiltration. The plot types were characterized as: plots with burned sugarcane waste (CQ) equivalent to $12 \mathrm{Mg} \mathrm{ha}^{-1}$ of burned waste; sugarcane without waste on the surface (CC0); sugarcane with $4.0 \mathrm{Mg} \mathrm{ha}^{-1}$ of waste (CC4); sugarcane with $8.0 \mathrm{Mg} \mathrm{ha}^{-1}$ of waste (CC8); sugarcane with $12.0 \mathrm{Mg} \mathrm{ha}^{-1}$ of waste (CC12); and sugarcane with $16 \mathrm{Mg} \mathrm{ha}^{-1}$ of waste (CC16). In the CQ treatment, the quantity of dry, burned waste corresponded to $12 \mathrm{Mg} \mathrm{ha}^{-1}$, which was the mean mass of waste observed after the crop was harvested. The treatments evaluated were $0 \%(\mathrm{CC} 0) ; 33 \%$ (CC4); 66\% (CC8); 100\% (CC12); 133\% (CC16), and $100 \%(\mathrm{CQ})$, of the mean productivity of waste obtained in the experimental area. The treatments were arranged in a randomized block design with four replications, totalling 24 experimental plots, each with an area of $0.70 \mathrm{~m}^{2}$. These plots were separated from each other by galvanized sheet steel with a funnel-shaped spout, allowing the runoff to be collected. Plant waste was characterized by the amount of dry mass of sugarcane waste crushed and spread across the surface of the soil in each experimental unit.

Simulated rain was applied using a rainfall simulator developed by Alves Sobrinho et al. (2008), calibrated at a rain intensity of $60 \pm 2 \mathrm{~mm} \mathrm{~h}^{-1}$. The rain applied by the rainfall simulator corresponded to $91 \%$ of the value of the kinetic energy of natural rainfall falling at the same intensity. The duration of each test using the rainfall simulator was $60 \mathrm{~min}$, timed from the start of surface runoff. Samples of runoff were collected at regular intervals of $2 \mathrm{~min}$, totalling 30 samples in each test. Thus, the depth of runoff was measured based on the volume of surface runoff and the area of the experimental plot. The depth of water infiltration was measured as the difference between the depth applied by the simulator and the runoff depth calculated every $60 \mathrm{sec}$. The instant infiltration rate was measured based on the infiltrated water depth and the time of collection. The stable infiltration rate (SIR) of water into the soil was measured after a constant runoff depth was observed.

Pre-wetting of each experimental plot was initiated using drippers, $24 \mathrm{~h}$ before the beginning of the tests. This was conducted in order to provide 
uniform moisture conditions, and as a prerequisite before the application of simulated rainfall (COGO et al., 1984). Before using the rainfall simulator, soil moisture was determined at a depth range of $0.0-0.20 \mathrm{~m}$ by the gravimetric method. The time of runoff initiation and the roughness of the soil surface were determined as an experimental control. The time of runoff initiation, recorded for each experimental plot, corresponded to the interval of time between the start of the application of rain with the simulator and the beginning of runoff. Surface roughness was measured $72 \mathrm{~h}$ after the completion of simulated rainfall, using a mechanical roughness tester consisting of 20 rods aligned three cm apart (PANACHUKI et al., 2010). This set of rods was moved at right angles relative to its alignment. Photographic records were obtained for 400 readings of the soil's microrelief height.

Suspended solids were decanted in four drops of $37 \%$ hydrochloric acid that were added to each flask from the field. After resting for $24 \mathrm{~h}$, the water was removed and measured, and the samples of solid material were placed in an oven at $60{ }^{\circ} \mathrm{C}$ until the weight of the dried materials was constant. Thus, the volume of the water drained and the mass of sediment from runoff was measured for each flask, and subsequently, the loss of water and soil was quantified.

The effect of the level of soil coverage on soil and water loss, and on the rate of water infiltration, was verified by means of the analysis of variance, with subsequent comparison of means at a $5 \%$ significance level using Tukey's test.

\section{Results and Discussion}

Soil macroporosity and soil bulk density values were lower in the superficial layer $(0.00-0.10$ $\mathrm{m})$, while the aggregate stability (mean geometric diameter and weighted mean diameter) declined as depth increased (Table 1). In general, the differences observed between soil depths were due to a lower content of organic matter at greater depths (SOUZA et al., 2005; PRADO et al., 2014), and the pressure exerted by the upper layers. In soybean cultivation, under no-tillage in Red Dystrophic Argisol, Panachuki et al. (2015) observed macroporosity values that ranged between $6.26 \%$ and $15.36 \%$, while the total porosity ranged between $26.55 \%$ and $34.63 \%$, with a mean geometric diameter range between 2.3 and $4.4 \mathrm{~mm}$.

Table 1. Mean values of macroporosity (Ma), total porosity ( $\mathrm{Tp}$ ), soil bulk density $(\mathrm{Sd})$, organic carbon $\left(\mathrm{C}_{\mathrm{org}}\right)$, mean geometric diameter (MGD), and weighted mean diameter (WMD).

\begin{tabular}{|c|c|c|c|c|c|c|}
\hline \multirow{2}{*}{$\begin{array}{c}\text { Depth } \\
(\mathrm{M}) \\
(\mathrm{m})\end{array}$} & $\mathrm{Ma}$ & $\mathrm{Tp}$ & \multirow{2}{*}{$\begin{array}{r}\mathrm{Sd} \\
\left(\mathrm{Mg} \mathrm{m}^{-3}\right)\end{array}$} & \multirow{2}{*}{$\begin{array}{r}\mathrm{C}_{\text {org }} \\
\left(\mathrm{g} \mathrm{kg}^{-1}\right)\end{array}$} & MGD & WMD \\
\hline & \multicolumn{2}{|c|}{$\left(\mathrm{m}^{3} \mathrm{~m}^{-3}\right)$} & & & \multicolumn{2}{|c|}{$(\mathrm{mm})$} \\
\hline $0.00-0.10$ & $0.11 \mathrm{a}$ & $0.38 \mathrm{a}$ & $1.42 \mathrm{c}$ & $25.62 \mathrm{a}$ & $2.08 \mathrm{a}$ & $3.00 \mathrm{a}$ \\
\hline $0.10-0.20$ & $0.06 \mathrm{~b}$ & $0.33 \mathrm{~b}$ & $1.54 \mathrm{~b}$ & $22.16 \mathrm{a}$ & $1.36 \mathrm{~b}$ & $2.21 \mathrm{~b}$ \\
\hline $0.20-0.40$ & $0.04 \mathrm{~b}$ & $0.30 \mathrm{c}$ & $1.61 \mathrm{a}$ & $15.42 \mathrm{~b}$ & $1.11 \mathrm{~b}$ & $1.74 \mathrm{~b}$ \\
\hline
\end{tabular}

* Mean values in columns followed by the same lowercase letter are not significantly different $(\mathrm{P}>0.05)$.

The critical limit of soil density is variable, and values close to, or above, $1.45 \mathrm{Mg} \mathrm{m}^{-3}$ are normally considered as a reference for most crops (CORSINI; FERRAUDO, 1999; REINERT et al., 2001; BAQUERO et al., 2012), although these values tend to increase with a decrease in clay content (ARSHAD et al., 1996). The values observed in the superficial layer of the soil $(0.00-0.10 \mathrm{~m})$ are not, according to this criterion, restrictive to root development. However, in the other depths evaluated, the values 
were higher than the critical threshold and may be considered as compressed. Soil layers with high values of soil bulk density, and low macroporosity, restrict the infiltration of water into the soil, and limit root growth (CORSINI; FERRAUDO, 1999). Regarding macroporosity values, Centurion et al. (2007) stated that values for this variable must be greater than $0.10 \mathrm{~m}^{3} \mathrm{~m}^{-3}$ to allow an adequate supply of air to enter the sugarcane root system. Thus, the macroporosity values (Table 1) observed between the depths of, 0.10 and $0.40 \mathrm{~m}$, are limiting to root development, and limit water infiltration into the soil, promoting runoff.

The values of MGD and MWD observed in the deepest layer of the soil $(0.20-0.40 \mathrm{~m})$ correspond to $46 \%$ and $42 \%$, respectively, of the values at the soil surface layer $(0.00-0.10 \mathrm{~m})$. This indicates that the aggregate stability declined as soil depth increased, as verified by Souza et al. (2005). These results were related to the presence of surface vegetation (SHUKLA et al., 2003), as well as a larger concentration of roots in the soil surface layer, which, after decomposing, add a greater amount of organic matter to the soil. This, according to Prado et al. (2014), contributes to the stability of the aggregates.

We found that the values of soil moisture prior to the rainfall tests ranged between $18.5 \%$ and $22.5 \%$ (Table 2). Since no significant differences were observed between the soil moisture values in each treatment, as recommended in the pre-wetting, it can be assumed that this variable did not influence the time of runoff initiation, loss of soil and water, and infiltration of water into the soil. We recorded shorter time intervals to observe the start of surface runoff in treatments without vegetative cover on the soil (e.g., treatments CQ and CC0) (Table 2). The time required to observe surface runoff in treatments with soil cover exceeded, on average, approximately 3.90 times the value observed in treatments without plant waste covering the surface. This finding highlights the influence of soil coverage by plant waste on delaying the start of surface runoff, by cushioning the impact of raindrops on the soil surface, favoring the infiltration of water into the soil, and acting as a physical barrier to runoff (KATO et al., 2009; PANACHUKI et al., 2011).

Table 2. Mean values of soil moisture for each treatment before the tests ( $\theta \mathrm{i}$ ), at the initiation of runoff (IT), and random roughness $(\mathrm{RR})$.

\begin{tabular}{ccccccc}
\hline & CQ & CC0 & CC4 & CC8 & CC12 & CC16 \\
\hline ii (\%) & $21.68 \mathrm{a}$ & $19.53 \mathrm{a}$ & $20.00 \mathrm{a}$ & $21.59 \mathrm{a}$ & $18.50 \mathrm{a}$ & $22.50 \mathrm{a}$ \\
\cline { 2 - 7 } IT $(\min )$ & $1.80 \mathrm{a}$ & $1.37 \mathrm{a}$ & $5.22 \mathrm{~b}$ & $6.42 \mathrm{~b}$ & $5.86 \mathrm{~b}$ & $7.18 \mathrm{~b}$ \\
RR $(\mathrm{mm})$ & $\mathrm{B}$ & $\mathrm{B}$ & The & The & The & The \\
\cline { 2 - 7 } & $11.65 \mathrm{a}$ & $12.42 \mathrm{a}$ & $12.02 \mathrm{a}$ & $12.48 \mathrm{a}$ & $13.55 \mathrm{a}$ & $11.72 \mathrm{a}$ \\
\hline
\end{tabular}

* Mean values in columns followed by the same lowercase letter are not significantly different $(\mathrm{P}>0.05)$. CQ $=\mathrm{Burned}$ sugarcane with $12 \mathrm{Mg} \mathrm{ha}^{-1}$ of burned waste; $\mathrm{CC} 0=$ Cane without plant waste on the surface; $\mathrm{CC} 4=\mathrm{Cane}$ with $4 \mathrm{Mg}^{-1}$ of waste; $\mathrm{CC} 8=\mathrm{Cane}$ with $8 \mathrm{Mg} \mathrm{ha}^{-1}$ of waste; $\mathrm{CC} 12=$ Cane with $12 \mathrm{Mg} \mathrm{ha}^{-1}$ of waste; $\mathrm{CC} 16=$ Cane with $16 \mathrm{Mg} \mathrm{ha}^{-1}$ of waste.

No significant variation was observed in the soil surface roughness of the treatments studied (Table 2). The similarity observed between the soil roughness values may be related to the thickness of the sugarcane leaves, which are the greatest contributors to plant waste remaining after a harvest. Thus, when randomly distributed on the surface of the soil, these leaves are not efficient in increasing soil roughness. However, sugarcane waste reduces the direct impact of rain drops on the surface of the soil, and acts as a barrier to surface runoff, which reduces the loss of soil and water, and increases water infiltration into the soil. 
Based on the values depicted in Figure 1, it can be assumed that the presence of sugarcane plant waste on the soil surface aids significantly in reducing the loss of soil and water. In the treatments without plant waste on the surface (e.g., CC0 and CQ), the accumulated losses of soil and water exceeded the mean value of the treatments with plant waste on the soil surface. However, this effect is more evident for soil loss than for water loss (Figure 1). The lower influence of soil cover on the reduction of water loss, compared to the reduction of soil loss, can be justified by the fact that soil has a limited storage capacity of water infiltrating the soil. Beyond this limit, the excess water runs off, reducing its effectiveness in controlling water losses by erosion (KOHNKE, 1968).

Figure 1. Mean values of soil loss $\left(10^{-2} \mathrm{Mg} \mathrm{ha}^{-1}\right)$ and water loss $(\mathrm{mm})$ as a function of different levels of soil cover: $\mathrm{CQ}=$ Burned Cane with $12 \mathrm{Mg} \mathrm{ha}^{-1}$ of burned waste; $\mathrm{CC} 0=$ Cane without plant waste on the surface; $\mathrm{CC} 4=\mathrm{Cane}$ with $4 \mathrm{Mg} \mathrm{ha}^{-1}$ of waste; $\mathrm{CC} 8=$ sugarcane with $8 \mathrm{Mg} \mathrm{ha}^{-1}$ of waste; $\mathrm{CC} 12=$ Cane with $12 \mathrm{Mg} \mathrm{ha}^{-1}$ of waste; $\mathrm{CC} 16=$ Cane with $16 \mathrm{Mg} \mathrm{ha}^{-1}$ of waste. (*): values differ from the other treatments, at a 5\% significance level, by Tukey's test.

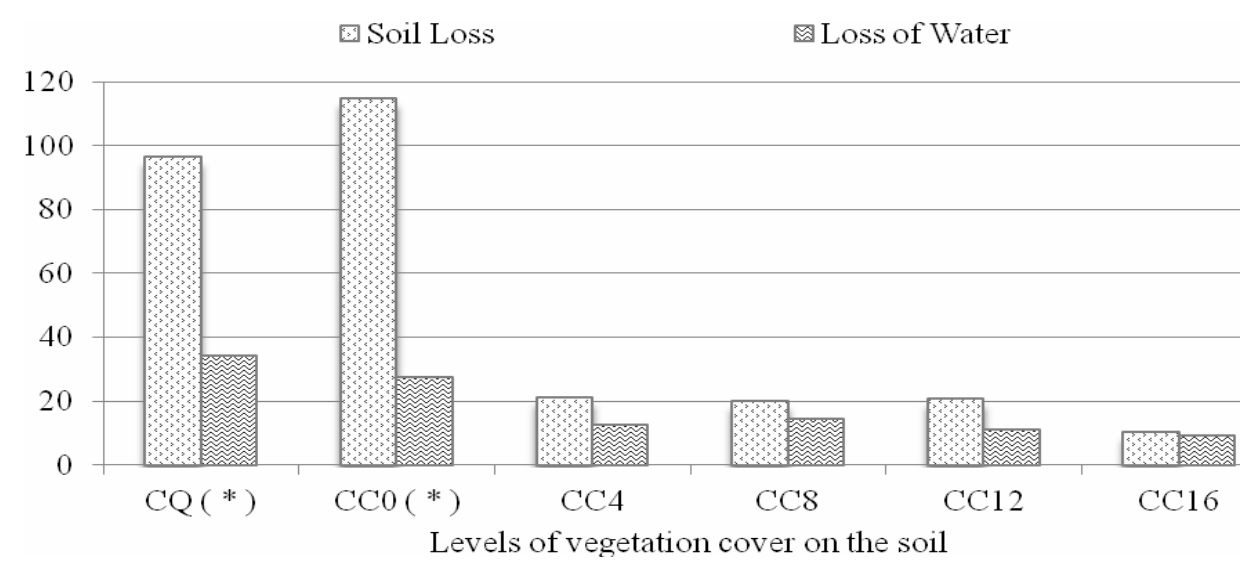

The largest losses of soil and water were observed in treatments without sugarcane waste on the surface, displaying a lower efficiency in controlling water erosion when vegetation covering the soil is removed, even under a no-till system. With the removal of vegetation, there is, therefore, a reduction in the value of the stable infiltration rate (SIR). On the other hand, studies have shown that the variation of the SIR can also be related to physical properties of the soil, such as density, porosity, and aggregate stability, that restrict the infiltration of water in the soil and limits root growth.

The fact that the greatest losses of soil and water are observed in the treatments without plant waste on the surface is related, according to Bezerra and Cantalice (2006), to the higher exposure of soil to the erosive action of raindrops that cause detachment of the particles and surface sealing of the soil (VOLK; COGO, 2008). Surface sealing reduces the rate of water infiltration and increases soil water runoff and the transport of particles (GARBIATE et al., 2011).

According to Silva et al. (2012), 75\% coverage with sugarcane waste should be implemented in order to minimize the loss of soil in interrill erosion, and $50 \%$ coverage for loss of water. In this study, the loss of soil and water were reduced when the amount of crop waste added corresponded to $33 \%$ (4 $\mathrm{Mg} \mathrm{ha}^{-1}$ ) of the total quantity produced by the crop (12 $\left.\mathrm{Mg} \mathrm{ha}^{-1}\right)$. Moreover, as observed by Martins Filho et al. (2009) and Silva et al. (2012), the increase in the amount of crop waste on the soil surface tends to exponentially reduce the loss of soil and water as a result of the interception of raindrops and the runoff that reduces the breakdown of soil 
particles provided by the presence of waste on the soil surface. Therefore, there is a threshold value of soil coverage from which the effects on soil and water conservation are minimal, allowing excess sugarcane waste to be used as a source of energy in alcohol plants.
The lowest SIR values were observed in treatments without soil coverage. The treatment with the highest amount of vegetation coverage on the soil surface $\left(16 \mathrm{Mg} \mathrm{ha}^{-1}\right)$ presented a SIR more than $100 \%$ higher than that of the treatments without soil coverage (Figure 2).

Figure 2. Stable Infiltration Rates (Mean $\pm \mathrm{SD}$ ) of water into the soil of areas cultivated with sugarcane as a function of different levels of soil cover: $\mathrm{CQ}=$ Burned sugarcane with $12 \mathrm{Mg} \mathrm{ha}^{-1}$ of burned waste; $\mathrm{CC} 0=$ Cane without plant waste on the surface; $\mathrm{CC} 4=$ Cane with $4 \mathrm{Mg} \mathrm{ha}^{-1}$ of waste; $\mathrm{CC} 8=$ Cane with $8 \mathrm{Mg}$ ha $^{-1}$ of waste; $\mathrm{CC} 12=$ Cane with $12 \mathrm{Mg} \mathrm{ha}^{-1}$ of waste; $\mathrm{CC} 16=$ Cane with $16 \mathrm{Mg} \mathrm{ha}^{-1}$ of waste.

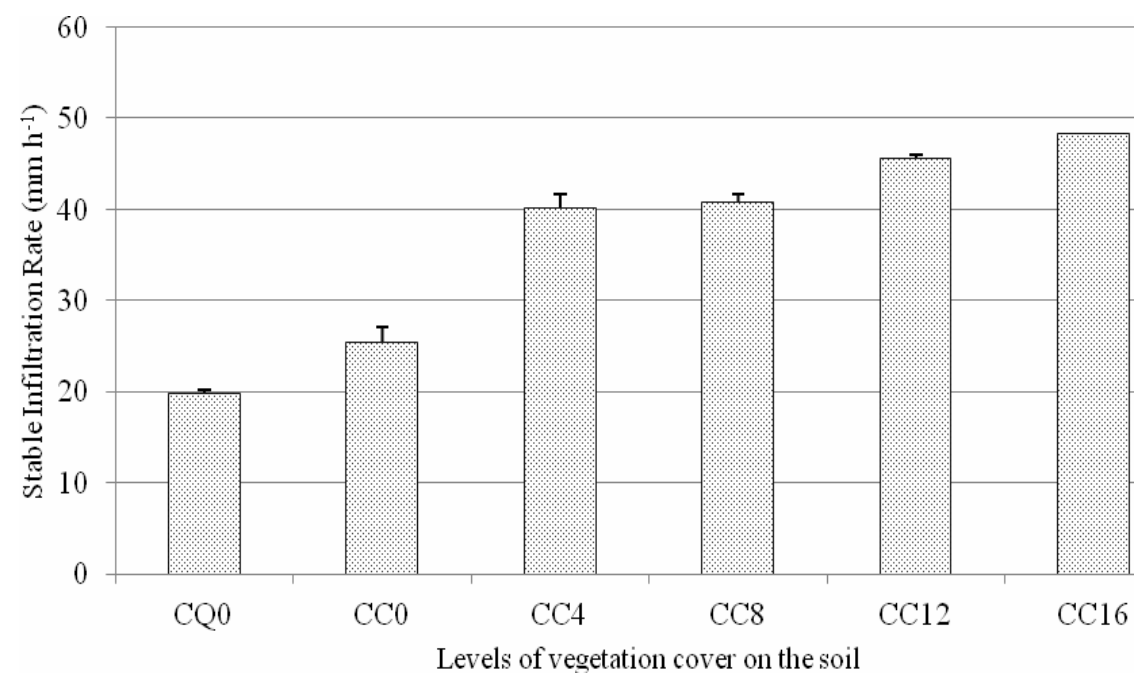

The highest SIR was observed in treatments with plant waste on the soil surface and may be due to the effect of these materials in absorbing and dissipating the impact energy of raindrops, thereby decreasing the breakdown of soil particles by acting as a barrier to the shearing energy of runoff (BEZERRA; CANTALICE, 2006). Thus, plant waste prevents sealing of the soil surface, which could reduce the rate of water infiltration into the soil.

With $4 \mathrm{Mg} \mathrm{ha}^{-1}$ of plant waste on the soil surface, we observed that the SIR was 66 and 99\% higher, respectively, than the $\mathrm{CQ}$ and $\mathrm{CC} 0$ treatments, which had no waste on the soil surface (Figure 2). In this situation (e.g., CC4), the SIR in the soil was similar to that of treatments $\mathrm{CC} 8$ and $\mathrm{CC} 12$ ( 8 and $12 \mathrm{Mg} \mathrm{ha}^{-1}$ ). The shortest duration to reach the SIR was observed in the CQ treatment, which had a pronounced reduction within the first 20 min of simulated rainfall (Figure 3). According to Silva (2007), the impact of raindrops displaces soil particles, and, subsequently, seals the soil surface, thereby reducing the infiltration of water into the soil. 
Figure 3. Variation in the rates of infiltration of water into the soil as a function of different levels of soil cover: CQ $=$ Burned sugarcane with $12 \mathrm{Mg} \mathrm{ha}^{-1}$ of burned waste; $\mathrm{CC} 0=$ Cane without plant waste on the surface; $\mathrm{CC} 4=\mathrm{Cane}$ with $4 \mathrm{Mg} \mathrm{ha}^{-1}$ of waste; $\mathrm{CC} 8=$ Cane with $8 \mathrm{Mg} \mathrm{ha}^{-1}$ of waste; $\mathrm{CC} 12=$ Cane with $12 \mathrm{Mg}^{-1}$ of waste; $\mathrm{CC} 16=$ Cane with $16 \mathrm{Mg} \mathrm{ha}^{-1}$ of waste.

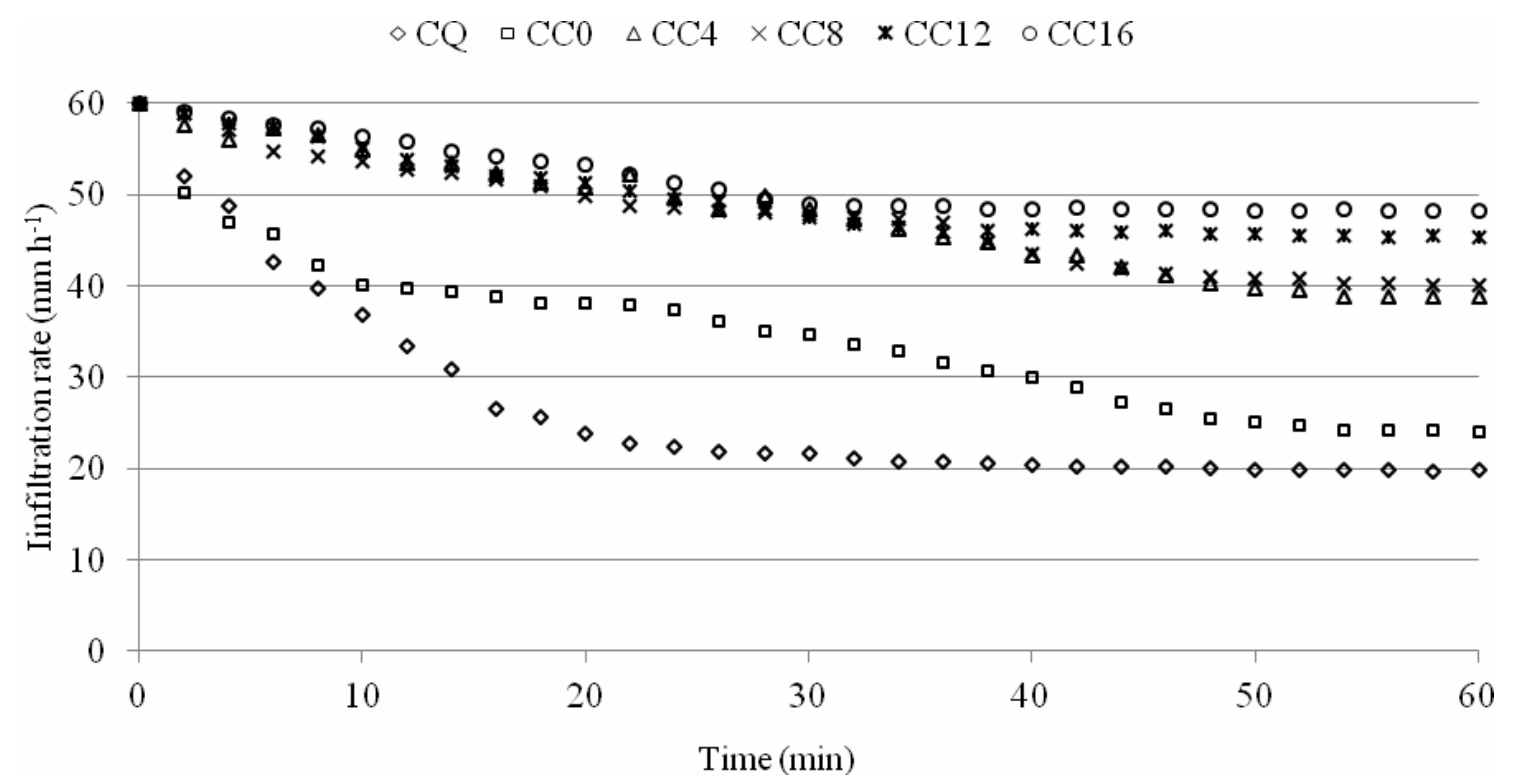

In cultivated areas where vegetation covering the soil surface was removed (e.g., CQ and CC0), the direct effect of raindrops on the soil resulted in a quick sealing surface, due to a reduction in soil porosity caused by the displacement of soil particles. In the $\mathrm{CQ}$ and $\mathrm{CC} 0$ treatments, the instant infiltration rate fell sharply within the first $20 \mathrm{~min}$ after surface runoff initiated. Consequently, the surface water depth was higher than in systems with plant waste on the soil surface. By contrast, in treatments with plant cover, the decrease in the instant infiltration rate was lower. However, within 30 minutes the infiltration rates of treatments, $\mathrm{CC} 4$ and $\mathrm{CC} 8$, showed a greater decline than those of $\mathrm{CC} 12$ and CC16 (Figure 3). Therefore, we infer that as soil plant trash cover increases, so does the rate at which water infiltration occurs.

The similarities between our soil surface roughness values (Table 2) allows us to infer that this variable did not affect the differences that occurred in the losses of soil and water, and the rate of water infiltration into the soil, indicating a greater effect of sugarcane plant waste on erosion and water infiltration into the soil.

\section{Conclusions}

There is a reduction of soil macroporosity, total porosity, organic carbon content, mean geometric diameter, and weighted mean diameter of soil aggregates as soil depth increased, while the bulk density of the soil displayed the opposite trend.

The presence of sugarcane waste on the soil surface increase the time required to initiate runoff.

Sugarcane waste do not alter soil surface roughness, and the minimum amount of plant waste administered (4 $\left.\mathrm{Mg} \mathrm{ha}^{-1}\right)$ reduce losses of soil and water, and increase the rate of water infiltration into the soil.

The lack of soil coverage after harvesting sugarcane favours soil and water loss and reduces the rate of water infiltration into the soil. 


\section{Acknowledgement}

To the Fundação de Desenvolvimento do Ensino, Ciência e Tecnologia of the state of Mato Grosso do Sul (FUNDECT) for providing financial support for the study.

\section{References}

ALVES SOBRINHO, T.; MACPHERSON, H. G.; GÓMEZ, J. A. A portable integrated rainfall and overland flow simulator. Soil Use Management, Oxford, v. 24, n. 2, p. 163-170, 2008.

AMARAL, J. A.; COGO, N. P.; BERTOL, I.; SANTOS, P. G.; WERNER, R. S. Erosão hídrica e escoamento superficial em função de tipos e doses de resíduo cultural em dois modos de semeadura direta. Revista Ciências Agroveterinárias, Lages, v. 12, n. 2, p. 163-174, 2013.

ARSHAD, M. A.; LOWERY, B.; GROSSMAN, B. Physical tests for monitoring soil quality. In: DORAN, J. W.; JONES, A. J. (Ed.). Methods for assessing soil quality. Madison: Soil Science Society of America, 1996. p. 123-141. (SSSA Special Publication, 49).

BAQUERO, J. E.; RALISCH, R.; MEDINA, C. C.; TAVARES FILHO, J.; GUIMARÃES, M. F. Propriedades físicas do solo e crescimento radicular de cana-de-açúcar em um Latossolo Vermelho. Revista Brasileira de Ciência do Solo, Viçosa, MG, v. 36, n. 1, p. 63-70, 2012.

BERTOL, I.; PAZ GONZÁLES, A.; VIDAL VÁZQUEZ, E. Rugosidade superficial do solo sob diferentes doses de resíduo de milho submetido à chuva simulada. Pesquisa Agropecuária Brasileira, Brasília, v. 42, n. 1, p. 103-110, 2007.

BEZERRA, S. A.; CANTALICE, J. R. B. Erosão entre sulcos em diferentes condições de cobertura vegetal de solo, sob cultivo da cana-de-açúcar. Revista Brasileira de Ciência do Solo, Viçosa, MG, v. 30, n. 3, p. 565-573, 2006.

CARVALHO, D. F.; CRUZ, E. S.; PINTO, M. F.; BATISTA DA SILVA, L. D.; GUERRA, J. G. M. Características da chuva e perdas por erosão sob diferentes práticas de manejo do solo. Revista Brasileira de Engenharia Agrícola e Ambiental, Campina Grande, v. 13, n. 1, p. 3-9, 2009.

CEDDIA, M. B.; ANJOS, L. H. C.; LIMA, E.; RAVELLI NETO, A.; SILVA, L. A. Sistemas de colheita da canade-açúcar e alterações nas propriedades físicas de um Podzólico Amarelo no Estado do Espírito Santo. Pesquisa Agropecuária Brasileira, Brasília, v. 34, n. 8, p. 1467-1473, 1999.
CENTURION, J. F.; FREDDI, O. S.; ARATANI, R. G.; METZNER, A. F. M.; BEUTLER, A. N.; ANDRIOLI, I. Influência do cultivo da cana-de-açúcar e da mineralogia da fração argila nas propriedades físicas de Latossolos Vermelhos. Revista Brasileira de Ciência do Solo, Viçosa, MG, v. 31, n. 31, p. 199-209, 2007.

COGO, N. P.; MOLDENHAUER, W. C.; FOSTER, G. R. Soil loss reductions from conservation tillage practices. Soil Science Society of America Journal, Madison, v. 48, n. 2, p. 368-373, 1984.

CORSINI, P. C.; FERRAUDO, A. S. Efeitos de sistemas de cultivo na densidade e macroporosidade do solo e no desenvolvimento radicular do milho em Latossolo Roxo. Pesquisa Agropecuária Brasileira, Brasília, v. 34, n. 2, p. 289-298, 1999.

GALDOS, M. V.; CERRI, C. C.; CERRI, C. E. P. Soil carbon stocks under burned and unburned sugarcane in Brazil. Geoderma, Amsterdam, v. 153, n. 3-4, p. $347-$ 352, 2009.

GARBIATE, M. V.; VITORINO, A. C. T.; TOMASINI, B. A.; BERGAMIN, A. C.; PANACHUKI, E. Erosão em entre sulcos em área cultivada com cana crua e queimada sob colheita manual e mecanizada. Revista Brasileira de Ciência do Solo, Viçosa, MG, v. 35, n. 6, p. 2145-2155, 2011.

GRAHAM, M. H.; HAYNES, R. J.; MEYER, J. H. Changes in soil chemistry and aggregate stability induced by fertilizer applications, burning and trash retention on a long-term sugarcane experiment in South Africa. European Journal of Soil Science, Oxford, v. 53, n. 4, p. 589-598, 2002.

KATO, H.; ONDA, Y.; TANAKA, Y.; ASANO, M. Field measurement of infiltration rate using an oscillating nozzle rainfall simulator in the cold, semiarid grassland of Mongolia. Catena, Cremlingen, v. 76, n. 3, p. 173-181, 2009.

KOHNKE, H. Soil physics. New York: McGraw-Hill, 1968. $224 \mathrm{p}$.

MARTINS FILHO, M. V.; LICCIOTI, T. T.; PEREIRA, G. T.; MARQUES JUNIOR, J.; SANCHEZ, R. B. Perdas de solo e nutrientes por erosão num Argissolo com resíduos vegetais de cana-de-açúcar. Engenharia Agrícola, Jaboticabal, v. 29, n. 1, p. 8-18, 2009.

PANACHUKI, E.; ALVES SOBRINHO, T.; VITORINO, A. C. T.; CARVAlHO, D. F.; URCHEI, M. A. Parâmetros físicos do solo e erosão hídrica sob chuva simulada em área de integração agricultura-pecuária. Revista Brasileira de Engenharia Agrícola e Ambiental, Campina Grande, v. 10, n. 2, p. 261-268, 2006. 
PANACHUKI, E.; BERTOL, I.; ALVES SOBRINHO, T.; OLIVEIRA, P. T. S.; RODRIGUES, D. B. B. Perdas de solo e de água e infiltração de água em Latossolo Vermelho sob sistemas de manejo. Revista Brasileira de Ciência do Solo, Viçosa, MG, v. 35, n. 5, p. 1777-1785, 2011.

PANACHUKI, E.; BERTOL, I.; ALVES SOBRINHO, T.; VITORINO, A. C. T.; SOUZA, C. M. A.; URCHEI, M. A. Rugosidade da superfície do solo sob diferentes sistemas de manejo e influenciada por chuva artificial. Revista Brasileira de Ciência do Solo, Viçosa, MG, v. 34, n. 2, p. 443-451, 2010.

PANACHUKI, E.; SANTOS, M. A. N.; PAVEI, D. S.; CAMACHO, M. A.; MONTANARI, R. Soil and water loss in Ultissol of the Cerrado-Pantanal Ecotone under different systems. African Journal of Agricultural Research, Abraka, v. 10, n. 9, p. 926-932, 2015.

PRADO, E. A. F.; VITORINO, A. C. T.; OLIVEIRA, W. H.; ESPINDOLA, D. L. P.; ARANTES, H. P. Índice de dispersão de agregados de um Latossolo Vermelho distroférrico cultivado com cana sob aplicação de vinhaça. Semina: Ciências Agrárias, Londrina, v. 35, n. 4, p. 2347-2356, 2014. Suplemento 1.

REICHERT, J. M.; SILVA, V. R. Propriedades físicas de solos em sistema de plantio direto irrigado. In: CARLESSO, R.; PETRY, M. T.; ROSA, G. M.; CERETTA, C. A. (Ed.). Irrigação por aspersão no Rio Grande do Sul. Santa Maria: UFSM, 2001. p. 114-133.

ROBERTSON, F. A. Sugarcane trash management: consequences for soil carbon and nitrogen - final report to the CRC for sustainable sugar production of the project nutrient cycling in relation to trash management. CRC for sustainable sugar production. Townville: Cooperative Research Centre for Sustainable Sugar Production, 2003. $39 \mathrm{p}$.
SCHIAVO, J. A.; PEREIRA, M. G.; MIRANDA, L. P. M.; DIAS NETO, A. H.; FONTANA, A. Caracterização e classificação de solos desenvolvidos de arenitos da formação Aquidauana-MS. Revista Brasileira de Ciência do Solo, Viçosa, MG, v. 34, n. 3, p. 881-889, 2010.

SHUKLA, M. K.; LAL, R.; OWENS, L. B.; UNKEFER, P. Land use management impacts on structure and infiltration characteristics of soils in the north Appalachian region of Ohio. Soil Science, Madison, v. 168, n. 3, p. 167-177, 2003.

SILVA, G. R. V.; SOUZA, Z. M.; MARTINS FILHO, M. V.; BARBOSA, R. S.; SOUZA, G. S. Soil, water and nutrient losses by interrill erosion from green cane cultivation. Revista Brasileira de Ciência do Solo, Viçosa, MG, v. 36, n. 3, p. 963-970, 2012.

SILVA, L. L. Fitting infiltration equations to centre-pivot irrigation data in a Mediterranean soil. Agricultural Water Management, Amsterdam, v. 94, n. 1-3, p. 83-92, 2007.

SOUZA, Z. M.; PRADO, R. M.; PAIXÃO, A. C. S.; CESARIN, L. G. Sistemas de colheita e manejo da palhada de cana-de-açúcar. Pesquisa Agropecuária Brasileira, Brasília, v. 40, n. 3, p. 271-278, 2005.

TOMINAGA, T. T.; CÁSSARO, F. A. M.; BACCHI, O. O. S.; REICHARDT, K.; OLIVEIRA, J. C. M.; TIMM, L. C. Variability of soil water contente and bulk density in a sugarcane field. Australian Journal of Soil Research, Victoria, v. 40, n. 4, p. 605-614, 2002.

VOLK, L. B. S.; COGO, M. P. Inter-relação biomassa vegetal subterrânea estabilidade de agregados-erosão hídrica em solo submetido a diferentes formas de manejo. Revista Brasileira de Ciência do Solo, Viçosa, MG, v. 32, n. 4, p. 1713-1722, 2008. 